\title{
Does the number of engaged screw threads affect the stability of slipped capital femoral epiphysis in the in situ fixation?
}

\section{Femur başı epifiz kaymasının in-situ tespitinde, epifiz hattını geçen vida yiv sayısı stabilitede etkili midir?}

\author{
Hüseyin GÜNAY ${ }^{1}$, Levent KÜÇÜK ${ }^{1}$, Murat Celal SÖZBİLEN² ${\text { Elcil KAYA BİÇER }{ }^{1} \text {, Mutlu ÇOBANOĞLU }}^{3}$ \\ ${ }^{1}$ Ege Üniversitesi Ortopedi ve Travmatoloji Anabilim Dalı, İzmir \\ ${ }^{2}$ Dr. Behçet Uz Çocuk Hastalıkları ve Cerrahisi EAH, Ortopedi ve Travmatoloji, İzmir \\ ${ }^{3}$ Adnan Menderes Üniversitesi Ortopedi ve Travmatoloji Anabilim Dall, Aydın
}

\section{ABSTRACT}

Objective: The management of slipped capital femoral epiphysis (SCFE) frequently seen in obese adolescents is fixation with cannulated screw. In this study, it was aimed to evaluate the relationship between the stability of the physis and the number of screw threads passing across the physeal line in the treatment of slipped capital femoral epiphysis (SCFE) with single screw fixation.

Methods: Thirty-three hips of 25 SCFE patients who had undergone in situ fixation with cannulated screw were included in the study. The mean age and follow up were 12.33 years (range, 7-16) and 42.24 \pm 16.65 months, respectively. The hips were grouped regarding to chronicity; acute, acute on chronic and chronic slips. The patients were also regrouped regarding the stability of the slip. Pre- and postoperatively both antero-posterior and frog leg pelvis radiographies were evaluated to measure Southwick slip angles and the number of screw threads.

Results: Metabolic or endocrinologic pathologies were observed in 13 patients. During the follow up four hips were reoperated due to the insufficiency of the screw threads passing across the physeal line. The mean number of the screw threads was 1,85 (range, 0-3) for the revised hips and 3.87 (range, 2-5) for the rest. The mean slip angle was $37.88^{\circ} \pm 15.2^{\circ}$ preoperatively. Postoperatively, the angle was reduced to $29.00^{\circ} \pm 16.41^{\circ}(\mathrm{p}=0.0001)$. Postoperative slip angles were significantly different between chronicity groups $(\mathrm{p}=0.019)$. In the acute slip group, mean slip angle was $21.00^{\circ} \pm 11.08^{\circ}$ whereas in the chronic group it was $42.22^{\circ} \pm 17.98^{\circ}(\mathrm{p}=0.009)$.

Conclusion: It was concluded that in the surgical treatment of SCFE with a single screw, the number of screw threads passing across the epiphyseal line should be at least four; otherwise fixation would not be stable enough.

Key words: Slipped capital femoral epiphysis, adolescent obesity, in-situ fixation, screw threads

$\ddot{\mathbf{O Z Z}}$

\begin{abstract}
Amaç: Adölesanlarda obezite ile birlikte sık görülen bir hastalık olan femur başı epifiz kaymasının (FBEK) tedavisi kanüllü vida ile in-situ tespittir. Bu çalışmada, tek kanüllü vida ile tedavi edilen FBEK'lerde epifizi geçen yiv sayısı ile stabilitenin ilişkisini saptamak amaçlanmıştır.

Yöntem: 2008-2013 yılları arasında kanüllï vida ile opere olan 25 FBEK hastasının 33 kalçası pre op ve post op olarak klinik ve radyolojik olarak değerlendirildi. Kalçalar etiyolojisine göre akut, kronik zeminde akut ve kronik olmak üzere gruplandırılırken, stabilite açısında gruplandırıldılar. Radyolojik olarak kalça tam AP ve frog-leg pozisyonlarında, operasyon öncesi ve sonrası Southwick açıları (epifiz-diafiz açısı), operasyon sonrası epifiz hattını geçen yiv sayıları ölçüldü̈.

Bulgular: On üç olguda metabolik veya endokrinolojik patoloji gözlendi. Tek kanüllü vida kullanılarak opere edilen olguların 4'ünde cerrahi sonrasında kayma açılarında artış olduğu gözlendi ve revize edildi. Bu 4 kalçada ön-arka ve frog-leg pozisyonlardaki grafilerde değerlendirilen epifiz hattını geçen yiv sayısı ortalaması 1.85 idi. Kayma açısında artış olmayan 29 kalçada ise yiv sayısı ortalaması $3.87 \mathrm{idi}(\mathrm{p}<0.001)$. Ortalama kayma açısı pre-operatif $37.88^{\circ} \pm 15.2^{\circ} \mathrm{iken}$, post-operatif $29.00^{\circ} \pm 16.41^{\circ}$ düştïğ̈̈i tespit edildi $(\mathrm{p}=0.0001)$. Post-operatif kayma açıları etiyolojiye göre değerlendirildiğinde ise, gruplar arası anlaml fark olduğu görïldüi $(p=0.019)$. Akut grupta ortlama kayma $21.00^{\circ} \pm 11.08^{\circ}$ iken, kronik grupta $42.22^{\circ} \pm 17.98^{\circ}$ idi $(p=0.009)$.

Sonuç: FBEK tedavisinde uygulanan tek kanüllü vida ile in-situ tespitte, epifiz hattını geçen vida yiv sayısı en az dört olmahıdır, aksi halde stabilite yetersiz olacaktır.
\end{abstract}

Anahtar kelimeler: Femur başı epifiz kayması, adölesan obezitesi, in-situ tespit, vida yiv sayısı
Alındığı tarih: 07.12.2016

Kabul tarihi: 10.02 .2017

Yazışma adresi: Uzm. Dr. Murat Celal Sözbilen, İsmet Kaptan Mah. Sezer Doğan Sok. No:11, Konak-İzmir

e-mail: muratcelal@hotmail.com 


\section{INTRODUCTION}

Slipped capital femoral epiphysis (SCFE) is commonly seen in obese adolescents. Surgical management with in situ fixation is a well-established method for acute, chronic, and acute-on-chronic cases with stable SCFE. Despite the current debates in its use in unstable acute SCFE cases, in situ fixation is widely used in current orthopaedic practice ${ }^{(1)}$.

The number and type of screws used for SCFE treatment depends on the preference of the surgeon, however, use of partially threaded cannulated screws with a thread diameter of $6.5 \mathrm{~mm}$, body diameter of $4.5 \mathrm{~mm}$, with the threaded portion long enough to engage the physis, is recommended ${ }^{(2)}$.

\section{PURPOSE}

Our aim is to investigate the effects of the number of screw threads that pass the epiphysis in SCFE patients who underwent in situ fixation with a single screw on the stability of epiphysis and prevention of postoperative slip progression.

\section{MATERIALS and METHODS}

Thirty-three hips of 25 patients who underwent in situ fixation with one single and same type of screw for SCFE between 2008 and 2013 were included in this study. There were 6 females (24\%) and 19 males (76\%), with a mean age of 12.44 years (ranging from 7 to 16 years). The mean duration of follow-up was $41.63 \pm 17.42$ months. Thirteen of the slips were on the right (39\%) while $20(61 \%)$ on the left side (Table 1$)$.

Table 1. Type of slip and number of cases.

\begin{tabular}{lccc}
\hline & Stable & Unstable & Total \\
\hline Acute & 5 & 4 & 9 \\
Acute on chronic & 4 & 2 & 6 \\
Chronic & 18 & 0 & 18 \\
\hline
\end{tabular}

Preoperative hip range of motion, the degree of shortness, duration of symptoms, history of trauma, accompanying endocrine and metabolic disorders, and familial characteristics of the patients were recorded.
Preoperative and postoperative Southwick's angles (the epiphyseal-shaft angle), the number of threads engaging the epiphyseal line after the operation were measured from radiographs taken in the AP and frogleg positions ${ }^{(3)}$. Follow-up X-rays were taken at early postoperative period, $3^{\text {rd }}, 6^{\text {th }}$, and $12^{\text {th }}$ months, and after one year, annual follow-up radiographs were obtained. The slip progression, epiphyseal irregularities, and findings of avascular necrosis were recorded.

\section{Surgical Technique}

Operations were performed by two experienced orthopedic surgeons. Four epiphysis passing threads were aimed during the operation.

With the patient under general anesthesia on a fracture table and with the hip in 10 degrees of internal rotation, a 1-2 cm incision was made on the lateral side under the tip of trochanter major. Anteroposterior and lateral images were obtained using a guidewire, and fixation was performed with partially threaded cannulated screw. Forceful traction and reduction maneuvers were avoided during the operation. A single cannulated screw was used in all patients. $(8.00 \mathrm{~mm}$ head diameter, 6.5 thread diameter, 3,5 hex.socket diameter,16 mm length of threads, Tipmed 6,5 cannulated screw ${ }^{\circledR}$ ). In order to avoid insufficient fixation, the screws were placed as close to the center of the epiphysis and perpendicular to the physis as possible in the AP and lateral positions ${ }^{(4)}$. We tried to ensure that the screw heads touched the lateral cortex of the femur and the screws with insufficient length to reach lateral cortex were attached with a bolt. All patients started partial weight-bearing with canadian crutches for 6 weeks postoperatively. Full unsupported weight-bearing was allowed in patients who had no clinical and radiological problems after 6 weeks.

\section{Statistical Analysis}

All statistical analyses were performed using SPSS v18.0. Parametric variables were analyzed with ANOVA, Fisher's exact test, and paired samples T tests while non-parametric Kruskal-Wallis test was used for multiple comparisons and the Mann-Whitney $\mathrm{U}$ test for pairwise comparisons. A p value of $<0.05$ was considered statistically significant. 


\section{RESULTS}

The patients had growth hormone disorders $(n=4)$, thyroid metabolism disorders $(\mathrm{n}=3)$, hypogonadism $(n=3)$, delayed puberty (1 girl), chronic renal insufficiency $(n=2)$, and Down syndrome $(n=1)$. Eleven patients had no comorbid pathologies. Eleven out of 33 hips had been exposed to fall related-trauma. Nine cases had acute, 6 cases had acute-on-chronic, and 18 cases had chronic slips. Epiphyseal slip was unstable in 6 hips, not allowing weight-bearing with or without support. Four out of these 6 hips were unstable in acute setting (Table 1).

The mean preoperative Southwick angle was $37.88 \pm 15.202$ whereas the mean postoperative angle was $29.00 \pm 16.411 \quad(\mathrm{p}<0.005$ paired samples test) (Table 2).

An analysis of postoperative angles revealed a significant difference between acute and acute-onchronic slips ( $\mathrm{p}=0.0007$ ANOVA post-hoc test). Although patients with chronic slips had no angle changes, those with acute slips and acute-on-chronic slips had reduction in the angle of slip postoperatively when compared to preoperative angles.

Table 2. Demografic datas, slipped angles and threads that passed epipyhseal line.

\begin{tabular}{|c|c|c|c|c|c|c|c|c|}
\hline Case & Age & Sex & Side & Number of threads & Preoperativeangle & Postoperativeangle & Type & Co-morbid \\
\hline 1 & 15 & M & Right & $2-3$ & 22 & 20 & $\mathrm{~S}$ & Hypothyroid \\
\hline 2 & 15 & M & Left & $0-0 / 4-4 *$ & 52 & $54-14 * *$ & $\mathrm{~S}$ & Hypothyroid \\
\hline 3 & 10 & M & Right & $2-3$ & 60 & 42 & $\mathrm{U}$ & Down syndrome \\
\hline 4 & 10 & M & Left & $4-3$ & 37 & 20 & $\mathrm{~S}$ & Down syndrome \\
\hline 5 & 13 & $\mathrm{~F}$ & Left & $5-4$ & 66 & 66 & $\mathrm{~S}$ & Delayed pubert \\
\hline 6 & 12 & M & Right & $5-5$ & 55 & 28 & $\mathrm{U}$ & Hyperthyroid \\
\hline 7 & 13 & M & Left & $4-3$ & 35 & 17 & $\mathrm{~S}$ & VSD \\
\hline 8 & 11 & M & Right & $4-4$ & 26 & 18 & $\mathrm{~S}$ & Adiposa genital \\
\hline 9 & 16 & M & Left & $4-4$ & 33 & 14 & $\mathrm{U}$ & Over growth \\
\hline 10 & 11 & M & Left & $3-2 / 5-4 *$ & 46 & $46-22 * *$ & $\mathrm{U}$ & - \\
\hline 11 & 12 & $\mathrm{~F}$ & Left & $3-3$ & 62 & 42 & $\mathrm{~S}$ & - \\
\hline 12 & 13 & M & Left & $3-1 / 4-4 *$ & 38 & $38-38 * *$ & $\mathrm{~S}$ & Over growth \\
\hline 13 & 11 & $\mathrm{~F}$ & Right & $4-4$ & 14 & 14 & $\mathrm{~S}$ & - \\
\hline 14 & 11 & $\mathrm{~F}$ & Left & $3-3$ & 45 & 15 & $\mathrm{~S}$ & - \\
\hline 15 & 13 & M & Right & $4-4$ & 33 & 12 & $\mathrm{~S}$ & Renal failure \\
\hline 16 & 13 & M & Left & $4-3$ & 21 & 21 & $\mathrm{~S}$ & Renal failure \\
\hline 17 & 7 & $\mathrm{~F}$ & Right & $3-2$ & 22 & 14 & $\mathrm{U}$ & Hypothyroid \\
\hline 18 & 14 & M & Left & $3-3$ & 52 & 52 & $\mathrm{~S}$ & - \\
\hline 19 & 15 & M & Left & $3-3$ & 28 & 16 & $\mathrm{~S}$ & - \\
\hline 20 & 13 & M & Left & $5-4$ & 54 & 54 & $\mathrm{~S}$ & Adiposa genital \\
\hline 21 & 15 & M & Right & $4-4$ & 28 & 16 & $\mathrm{~S}$ & - \\
\hline 22 & 16 & M & Left & $5-5$ & 36 & 24 & $\mathrm{~S}$ & - \\
\hline 23 & 9 & $\mathrm{~F}$ & Right & $4-4$ & 46 & 46 & $\mathrm{~S}$ & Renal failure \\
\hline 24 & 9 & $\mathrm{~F}$ & Left & $5-4$ & 52 & 52 & $\mathrm{~S}$ & Renal failure \\
\hline 25 & 10 & $\mathrm{~F}$ & Right & $4-4$ & 28 & 16 & $\mathrm{~S}$ & - \\
\hline 26 & 14 & M & Right & $3-4$ & 32 & 14 & $\mathrm{~S}$ & - \\
\hline 27 & 14 & M & Left & $5-5$ & 28 & 20 & $\mathrm{~S}$ & - \\
\hline 28 & 13 & M & Left & $5-4$ & 16 & 30 & $\mathrm{~S}$ & Over growth \\
\hline 29 & 11 & M & Right & $5-4$ & 54 & 16 & $\mathrm{U}$ & Leukemia \\
\hline 30 & 11 & M & Right & $5-4$ & 20 & 20 & $\mathrm{~S}$ & Adiposa genital \\
\hline 31 & 11 & M & Left & $5-4$ & 30 & 26 & $\mathrm{~S}$ & Adiposa genital \\
\hline 32 & 13 & M & Right & $5-4$ & 16 & 16 & $\mathrm{~S}$ & Over growth \\
\hline 33 & 13 & M & Left & $0-1 /$ ost & 57 & $60-32 * *$ & $\mathrm{~S}$ & Over growth \\
\hline
\end{tabular}

*= The number of threads engaging the epiphysis after revision

$* *=$ Pre- and post-revision angles in patients who required revision

ost $=$ femoral valgisation osteotomy was performed for revision.

number of threads= the number of threads engaging the epiphysis as imaged by hip AP - Frog-leg

radiographs.

$S=$ Stable

U=Unstable 
Four hips were unstable due to the low number of threads engaging the epiphysis, and loosening of the cannulated screw, of which 2 had persistent epiphyseal slips with an increased Southwick's angle. One patient with increased angle had screw replacement while the other patient who had short stature and coxa vara deformities due to epiphyseal closure underwent a valgisation osteotomy. One hip had a revision immediately after operation based on the findings on postoperative radiographs which showed screw threads were far away from the epiphyseal line. In these four hips which were deemed to have inadequate fixation, the average number of threads crossing the epiphyseal line was 1.25 (0-3). The mean number of threads in three revised hips which had placement of cannulated screws was at least 4 . Twenty-nine hips, in which sufficient stability was achieved, had a mean number of threads of 3.87 (2-5). The rate of revision operation was significantly higher in those with less than 3.87 threads (Fisher'sexact test $\mathrm{p}<0.003$ and Mann- Whitney $U$ test $\mathrm{p}<0.02$ ). One of our patients, a 7 year-old girl, who had a small proximal femur physis which allowed us to place 2 threads, had no increased angle or slip during followup (Figure 1). In one of our cases, who had Down syndrome, threads of the cannulated screw broke at
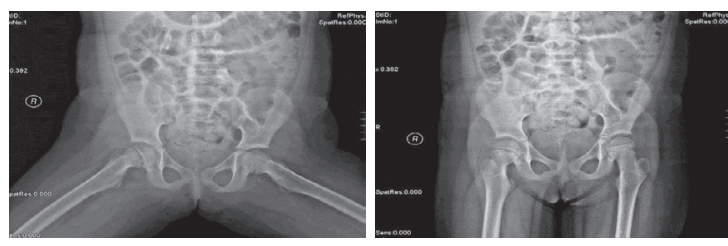

a


Figure 1a. 7 y old chronic stable SCFE. Preoperative X-ray. b. Postoperative frog-leg AP and X-ray aspect. 2 threads are passing physeal line in image. c. Postoperative 35. Months. the proximal portion at 15 months postoperatively, despite the presence of sufficient number of threads engaging the epiphysis and achievement of stability (Figure 2). Among all hips, 1 out of 4 cases with acute unstable slip had avascular necrosis and another case had chondrolysis. No infection was observed in our series.

A measurement of Southwick's angles after revision revealed a statistical significance $(\mathrm{p}=0.015)$. There was no increase in the postoperatively measured angles among patients who underwent revision surgeries.
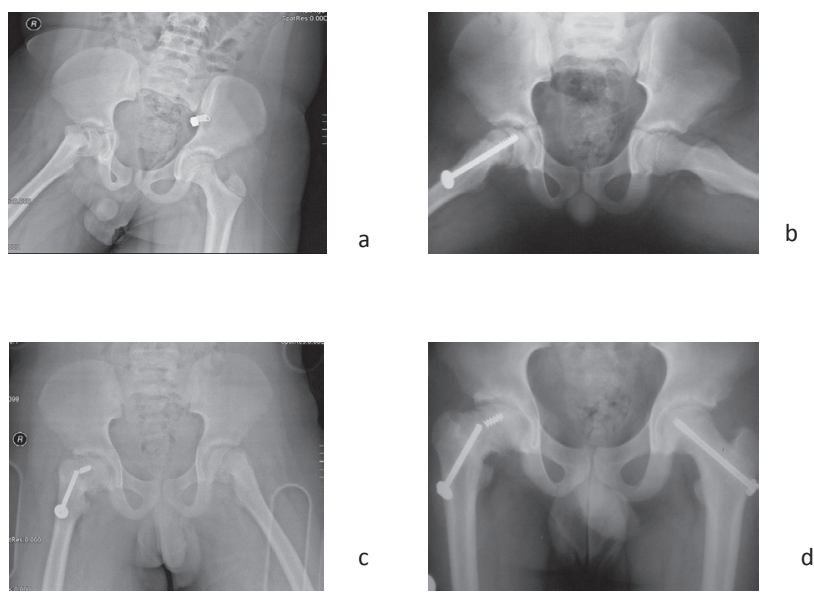

Figure 2a. 10 years old patient with Down syndrome. Preoperative image of acute unstable SCFE. b. Postoperative 0 day frog-leg X-ray. c. Postoperative 15. months failure of screw was seen in antero-posterior image and acute SCFE was occured in contralateral hip. d. Postoperative 32. months image.
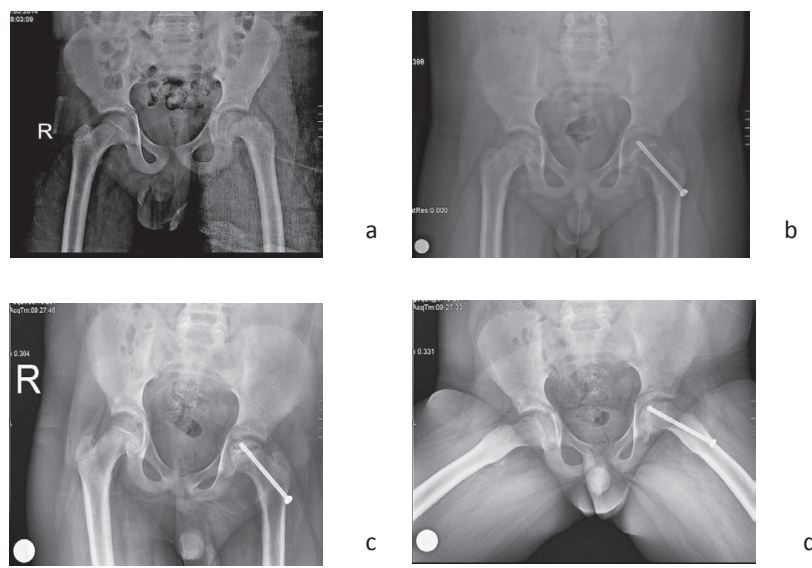

d

Figure-3 a. 11 years old patient with acute unstable SCFE. b. Postoperative 0. day X-ray. c. Avasculer necrosis was occured at postoperative 7 . months antero-posterior X-ray. d. Avasculer necrosis in frog leg X-ray. 


\section{DISCUSSION}

Our study aimed to determine the effective number of threads engaging the epiphyseal line required for achieving stability. Carney, et al. reported a progression rate of $20 \%$ in 46 hips which were treated with in situ single cannulated screw fixation. All hips that deteriorated had less than 5 screw threads engaging the epiphyseal line on postoperative radiographs ${ }^{(5)}$. A biomechanical study using $7.3 \mathrm{~mm}$ stainlesssteel AO screw (5 threads) by Upasani, et al. ${ }^{(6)}$ reported that femurs with 2 or 3 threads across the physis had a greater load to failure and stiffness compared to femurs with 1, 4 or 5 threads across the pysis. In our study, single cannulated screws were used in all cases and 4 hips (12\%) had insufficient stability due to the inadequate number of threads. The mean number of threads that are required to obtain stability was 4 (mean of 3.87). In none of SCFE cases with thread numbers of 4 or more had increased angle.

It is well-known that hormonal imbalances, particularly hypothyroidism, might adversely affect the hypertrophic zone of the epiphysis, thus causing a slip ${ }^{(7)}$. It is also known that endocrinologic problems constitute risk factors for SCFE, however, current literature is limited to case reports for the effects of these risk factors on epiphyseal instability after screw fixation. Walter RP, et al. ${ }^{(8)}$ reported that a patient with acute bilateral SCFE, undergoing thyroid replacement therapy, experienced epiphyseal migration off and loosening of bilateral screws 12 months after the operation. In our study, loosening was noted in one hip of four hips of 3 patients with thyroid metabolism disorder in the early period, and required screw revision. However, since this loosening was unilateral, this complication was attributed to the inadequate number of threads (only 1 thread) engaging the epiphysis in the initial operation rather than thyroid metabolism disorder. After revision, no loosening was observed at 48 months of the follow-up period .

There are several preoperative and postoperative factors that affect the stability of femoral epiphysis. Loder, et al. ${ }^{(9)}$ reported that the single most important factor for the stability of physis was whether the slip was stable or unstable. Hagiwara, et al. (10) also demonstrated that the insertion of the screw in the proximal aspect had great significance for stability. Studies conducted in SCFE patients revealed that when a single screw, inserted from the lateral side of the proximal femoral metaphysis to the intertrochanteric line, prevented slip progression without a risk for intraarticular penetration ${ }^{(10)}$. In 9 cases, the contact between the screw head and the cortical bone at the insertion site was managed with 1 or 2 bolt-nuts, particularly in long screws. A study of patients treated for SCFE by Fallath, et al. ${ }^{(11)}$ reported that 73 patients had stable and 14 had unstable slips, and 4 cases ( 2 stable and 2 unstable) required screw revision. One case with unstable slip, which was fixed with a single screw, experienced continued slippage and the other case had screw migration out of the epiphysis at 10 months despite good initial positioning which were attributed to the growth hormone deficiency.

Despite the current debates on the correct number of screws in the literature, a 6.5-7 mm screw is accepted to provide adequate epiphyseal stability by most authors ${ }^{(12)}$. In a study conducted among orthopedic surgeons surveyed by e-mail and fax, who were all members of POSNA, $57.3 \%$ of the surgeons reported that even in acute unstable SCFE cases, they had used single-threaded screws and $40.3 \%$ of them had employed 2-threaded screws for fixation ${ }^{(13)}$. The same study showed that $65.8 \%$ of the surgeons performed surgical procedures on the fracture table and $11.8 \%$ used reduction by manipulation before fixation ${ }^{(13)}$. All of our cases (acute, chronic and acute-onchronic, stable and unstable) were operated on using a single partially threaded cannulated screw on the fracture table without applying forceful manipulation and traction, with the hip and knee extended and internally rotated 10 degrees. It was found that the use of a fracture table enabled sufficient manipulation and re-positioning of the patient when needed, and easy acquisition of lateral imaging using scopy during the operation without moving the patient.

The significant decrease in Southwick's angles in acute and subacute patients in early postoperative period was deemed to indicate that performing surgical procedure on the fracture table with slight internal 
rotation might contribute to the reduction ${ }^{(14)}$. One case had avascular necrosis and another case had chondrolysis. None of the chronic cases had significant decrease in Southwick's angle postoperatively. Cobanoglu, et al. ${ }^{(15)}$ studied chronic stable cases in whom reduction maneuver was not performed by using the fracture table and obtained clinical and radiological success using single screw fixation.

In a study by Basar, et al. ${ }^{(16)}$ one out of 34 hips undergoing in situ single screw fixation had avascular necrosis at 60 months. Similar to their results, one of our patients with acute unstable slip greater than 50 degrees had avascular necrosis 7 months after the initial surgery (Figure 3).

In this study, the number of screw threads required for achieving stability, BMI, history of trauma, and additional comorbidities other than hormonal and metabolic diseases were investigated. On the other hand, possible limitation of the study might be the lack of information about standard mechanical characteristics (quality of reduction, quality of screw placement). One other weak point might be the lack of knowledge about the length of the screw part that passes into epiphysis. Equal epiphysis passing lengths with different thread counts would be more determinative in this study, but this determination could not be achieved due to retrospective design of the study and limited number of patients. In addition, data on epiphyseal closure could not be included in this study due to limited follow up period restricted to 2-5 years.

\section{CONCLUSION}

Despite current debates on its efficacy in acute unstable SCFE, single screw in situ fixation, which is accepted to be a treatment option for all SCFE subtypes, can provide sufficient stability if it is ensured that adequate number of screw threads have engaged the epiphysis. The presence of 3 or less threads engaging the ephysis constitutes a risk for epiphyseal slip in SCFE patients. Independent of the underlying etiologies, when adequate cortical support is obtained at the insertion site, a single screw method will be sufficient to prevent slip progression in SCFE where 4 or more threads engage the epiphysis.

\section{REFERENCES}

1. Wegner, Dennis R, Bomar, James D. Acute, unstable, slipped capital femoral epiphysis: Is there a role for in situ fixation? J Pediatr Orthop 2014;(34):11-17.

2. John Antony Herring MD.(editor). Taschdjian's Pediatric Orthopaedics $5^{\text {th }}$ edition vol:1 p:630-655.

3. Southwick WO. Osteotomy through the lesser trochanter for slipped capital femoral epiphysis. J Bone Joint Surg Am 1967;49(5):807-835 https://doi.org/10.2106/00004623-196749050-00001

4. Loder RT. Slipped capital femoral epiphysis in children. Curr Opin Pediatr 1995;7(1):95-7.

https://doi.org/10.1097/00008480-199502000-00018

5. Carney BT, Birnbaum P, Minter C. Slip progression after in situ single screw fixation for stable slipped capital femoral epiphysis. J Pediatr Orthop 2003;23:584-589. https://doi.org/10.1097/01241398-200309000-00004

6. Hagiawara S, Nakamura J, Kamegaya M, Saisu T, Kakizaki J, Ohtori S, Kishida S, Takahashi K. Lateral insertion is a good prognostic factor after in situ fixation in slipped capital femoral epiphysis. BMC Musculoskelet Disord 2014;26(15):317. https://doi.org/10.1186/1471-2474-15-317

7. Upasani V, Kishan S, Oka R, Mahar A, Rohmiller M, Pring $\mathrm{M}$, Wegner D. Biomechanical analysis of single screw fixation for slipped capital femoral epiphysis: are more threads across the physis necessary for stability? J Pediatr Orthop 2006;26(4):474-8. https://doi.org/10.1097/01.bpo.0000217732.24041.81

8. Walter RP, Jeffery RS, Holroyd B. Bilateral epiphyseal migration following fixation for slipped capital femoral epiphyses in a hypothyroid child. Acta Orthop Belg 2013;79(2):235-8.

9. Loder RT, Richards BS, Shapiro PS, Reznick LR, Aronson DD. Acute slipped capital femoral epiphysis; the importance of physeal instability. J Bone Joint Surg Am 1993;75(8):1134-40. https://doi.org/10.2106/00004623-199308000-00002

10. Loder RT, Wittenberg B, DeSilva G. Slipped capital femoral epiphysis associated with endocrine disorders. J Pediatr Orthop 1995;15(3):349-56. https://doi.org/10.1097/01241398-199505000-00018

11. Salah Fallath, Mery Letts. Slipped capital femoral epiphysis: an analysis of treatment outcome according to physeal stability. Can J Surg 2004;47(4):284-289.

12. Ward WT, Stefko J, Wood KB, Stanitski CL. Fixation with a single screw for slipped capital femoral epiphysis. J Bone Joint Surg Am 1992;74(6):799-809. https://doi.org/10.2106/00004623-199274060-00001

13. Mooney JF 3rd, Sanders JO, Browne RH, Anderson DJ, Jofe M, Feldman D, Raney EM. Management of unstable/acute slipped capital femoral epiphysis: results of a survey of the POSNA membership. J Pediatr Orthop 2005;25(2):162-6. https://doi.org/10.1097/01.bpo.0000151058.47109.fe

14. De Sanctis N, Di Gennaro G, Pempinello C, Corte SD, Carannante $\mathrm{G}$. Is gentle manipulative reduction and percutaneous fixation with a single screw the best management of acute and acute-on-chronic slipped capital femoral epiphysis? A report of 70 patients. J Pediatr Orthop B 1996;5(2):90-5. https://doi.org/10.1097/01202412-199605020-00007

15. Cobanoglu M, Cullu E, Ozkan I. How effective is in situ pinning with single screw fixation in mildly or moderately slipped capital femoral epiphysis? Eklem Hastalik Cerrahisi 2014;25(1):30-5. https://doi.org/10.5606/ehc.2014.07

16. Başar H, Kıyak G, Caypınar B, Erol B. Effects of the grade, stability, chronological classification and being either unilateral or bilateral of the slip on the treatment by in situ single screw fixation of patients with slipped capital femoral epiphysis. Arch Orthop Trauma Surg 2012;132(12):1671-6. https://doi.org/10.1007/s00402-012-1577-5 